\title{
Maastricht University graduate surveys 2015
}

Citation for published version (APA):

Levels, M. (2015). Maastricht University graduate surveys 2015. ROA. ROA Fact Sheets No. 002 https://doi.org/10.26481/umarof.2015002

Document status and date:

Published: 01/01/2015

DOI:

10.26481/umarof.2015002

Document Version:

Publisher's PDF, also known as Version of record

\section{Please check the document version of this publication:}

- A submitted manuscript is the version of the article upon submission and before peer-review. There can be important differences between the submitted version and the official published version of record.

People interested in the research are advised to contact the author for the final version of the publication, or visit the DOI to the publisher's website.

- The final author version and the galley proof are versions of the publication after peer review.

- The final published version features the final layout of the paper including the volume, issue and page numbers.

Link to publication

\footnotetext{
General rights rights.

- You may freely distribute the URL identifying the publication in the public portal. please follow below link for the End User Agreement:

www.umlib.nl/taverne-license

Take down policy

If you believe that this document breaches copyright please contact us at:

repository@maastrichtuniversity.nl

providing details and we will investigate your claim.
}

Copyright and moral rights for the publications made accessible in the public portal are retained by the authors and/or other copyright owners and it is a condition of accessing publications that users recognise and abide by the legal requirements associated with these

- Users may download and print one copy of any publication from the public portal for the purpose of private study or research.

- You may not further distribute the material or use it for any profit-making activity or commercial gain

If the publication is distributed under the terms of Article $25 \mathrm{fa}$ of the Dutch Copyright Act, indicated by the "Taverne" license above, 
Tuastricht University in Learning!

Research Centre for Education and the Labour Market | ROA

\section{Maastricht University graduate surveys 2015}

\section{ROA Fact Sheet}

ROA-F-2015/2

Researchcentrum voor Onderwijs en Arbeidsmarkt | ROA Research Centre For Education and the Labour Market / ROA 


\section{Maastricht University graduate surveys 2015}

To what degree does Maastricht University succeed in preparing its students for the labour market? What are the short and medium term career paths of Maastricht University alumni, and how do they look back on their study in Maastricht? In this factsheet, the most important results of a 2014/20I5 survey amongst three cohorts of Maastricht University alumni are presented. The first cohort graduated in the academic year 20I2-20I3 (I.5 years prior to the survey), the second cohort graduated in 2008-2009 (6 years prior to the survey) and the third cohort in the academic year 2003-2004 (II years prior to the survey). ${ }^{1,2}$

\section{Position in the labour market}

Six to eleven years after graduation, around $96 \%$ of the Maastricht university alumni have paid employment. Overall, approximately $2-3 \%$ of graduates in both cohorts reported to be out of the labour force. Important reasons for inactivity include participating in further education or taking care of children or relatives. A small percentage of graduates is looking for work. Table I gives a more detailed overview of graduates' unemployment rates - that is, the proportion of graduates who are currently not working but who are searching for work - by cohort and faculty. Overall, $9 \%$ of the 20I2-20I3 cohort is currently unemployed, while this only applies to $3 \%$ of the 2008-2009 cohort and $2 \%$ of the 2003-2004 cohort. ${ }^{3}$ The higher unemployment rate of the 20I2-20I3 cohort seems to be a clear reflection of the recent economic crisis, that hampers the transition from university to work.

In the 20I2-2013 cohort, unemployment rates are highest among Law graduates. However, in the 2008-2009 cohort, unemployment rates are the highest among Psychology and Neuroscience graduates, while in the 2003-2004 cohort the highest rate is seen for Arts and Social Sciences graduates. ${ }^{4}$ We can conclude that labour market participation is higher for the 2008-2009 and 2003-2004 cohorts of Maastricht university graduates, but is considerably lower for the 20122013 cohort.

I Of the 20I2-20I3 cohort, 2778 respondents were approached, of whom $22 \%$ responded. For the 2008-2009 cohort, of the 1639 alumni approached, 33\% responded. Finally, for the 2003-2004 cohort, of the I736 alumni that were approached, $36 \%$ responded.

2 The reader should keep in mind that the mix of studies offered by Maastricht University the respondents graduated from may vary between the three cohorts.

3 The unemployment rate might also vary within faculties. For example, in case of the Faculty of Health, Medicine and Life Sciences, the unemployment of Medical alumni is $3 \%$ I.5 years after graduation, whereas for Health and life Sciences alumni the unemployment rate among the same cohort is IO\%.

4 It has to be noted that in the 2003-2004 cohort too few cases from Humanities and Science were available for statistical analysis.
Table 1

Unemployment

\begin{tabular}{l|c|c|c|} 
& \multicolumn{3}{|c|}{ \% unemployed } \\
\hline Humanities and Science & $2012-2013$ & $2008-2009$ & 2003-2004 \\
\hline Business and Economics & 13 & 0 & $\mathrm{x}$ \\
\hline Health, Medicine and Life Sciences & 8 & 1 & 1 \\
\hline Arts and Social Sciences & 14 & 2 & 2 \\
\hline Psychology and Neuroscience & 8 & 8 & 4 \\
\hline Law & 16 & 3 & 2 \\
\hline Maastricht University & 9 & 3 & 1 \\
\hline x= too few cases & & & 2 \\
\hline
\end{tabular}

Trends in unemployment

To what extent has the recent economic crisis affected labour market opportunities of Maastricht University graduates since 2008? An indication can be found in the average unemployment rate of Maastricht university graduates, as reported by the surveys that were held between 2005 and 20I4. For all ten years that these surveys were conducted, unemployment information of the three cohorts is available. For the two cohorts that are 6 or II years on the labour market, no visible trend in unemployment rates can be detected. Thus, the most recent economic crisis does not seem to have had an influence on the unemployment rate of Maastricht University alumni 6 to II years into their labour market. Nevertheless, a notable increase in unemployment rates can be observed when analysing the data of alumni who graduated one year prior to the survey (see Figure I). However, for the first time since the onset of the crisis in 2008 , we can see a drop in the unemployment rate in 2014 . In Appendix A, yearly employment rates are reported per faculty.

\footnotetext{
It should be noted that compared to preceding years, in 2015 we use a slightly different definition of employment status in the surveys among alumni who graduated 6 and II years prior to the survey. Whereas prior to 2015 a respondent had to report a working week of at least I2 hours to be considered as employed, from 2015 onwards the International Labour Organisation (ILO) definition applies, whereby all those who reported at least one hour of work are considered to be employed. In practice this makes little difference, since the vast majority of those employed are working fulltime, but it is possible that a small part of the change in unemployment in 2015 in those cohorts can be attributed to the definition change.
} 
Figure 1

Trends in unemployment of the T+1 survey

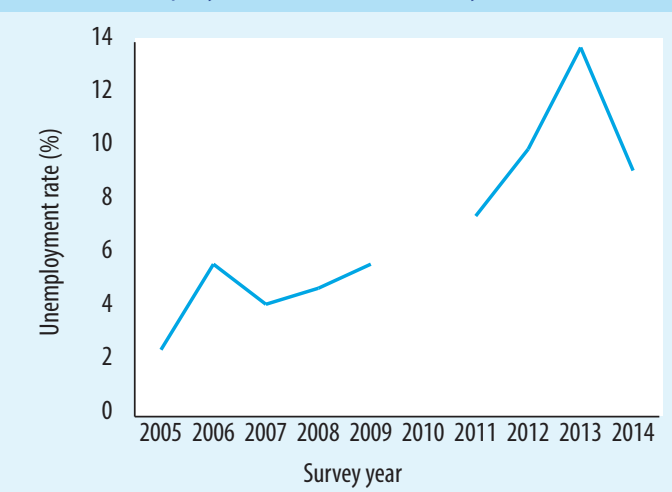

1 the $T+1$ survey was not administered in 2010

\section{Job characteristics}

It is important that graduates have a good match between their education and the requirements of their job, since this determines the extent to which they can use their knowledge and skills. ${ }^{6}$ The quality of the education-job match is positively related to job satisfaction, career opportunities, and wages. An important indicator of the quality of the fit between education and the job is the vertical match (i.e., whether graduates are working in a job that requires an academic degree). Table 2 a shows the results of the vertical match between graduates' current job and their level of education, for all three cohorts.

Table 2a

Vertical match

\begin{tabular}{|l|c|c|c|}
\hline & \multicolumn{4}{|c|}{ \% working at university level or higher } \\
\hline Humanities and Science & $2012-2013$ & $2008-2009$ & $2003-2004$ \\
\hline Business and Economics & 96 & 77 & $\mathrm{X}$ \\
\hline Health, Medicine and Life Sciences & 81 & 82 & 93 \\
\hline Arts and Social Sciences & 84 & 94 & 92 \\
\hline Psychology and Neuroscience & 81 & 66 & 89 \\
\hline Law & 75 & 90 & 95 \\
\hline Maastricht University & 82 & 88 & 98 \\
\hline x= too few cases & 82 & 85 & 93 \\
\hline
\end{tabular}

Table 2 a clearly shows that the vast majority of graduates succeeds in finding a job at an appropriate level. However, the results of the vertical match are substantially different for the three cohorts. Among graduates from Maastricht University as a whole, the proportion of well-matched respondents decreases from $93 \%$ for the oldest cohort to $82 \%$ for the youngest cohort. Although there are some

6 See for example: R. van der Velden (20II), De effecten van betrouwbaarheid van onderwijsdiploma's op arbeidsproductiviteit: toepassing van een simulatiemodel, In: J.Dronkers (ed.), Goede bedoelingen in het onderwijs: Kansen en missers, boekaflevering Mens en Maatschappij, pp 27-49. fluctuations between the cohorts, in general we may see relatively lower proportions of well-matched graduates in the Faculty of Arts and Social Sciences and (the youngest cohort of) the Faculty of Psychology and Neuroscience, and relatively high proportions in the Faculties of Health, Medicine and Life Sciences and Law. ${ }^{7}$ We also see a high proportion for Humanities and Science graduates in 201220I3. This last observation is based on very small numbers however, and so should be treated with caution.

Table $2 \mathrm{~b}$ presents numbers on the horizontal educationto-job match. This indicator measures the proportion of Maastricht University graduates who currently work in a job that requires their own or a related field of study. Again, it should be noted that most graduates succeed in finding a job in a field that well-matches their field of study. The three cohorts have different matching rates, with the results being most positive for the 2008-2009 cohort. However, we see no clear trend. Six years after graduation, $84 \%$ of the Maastricht University graduates are working in a job that matches well with their field of study, while 1,5 and II years after graduation, respectively $77 \%$ and $80 \%$ of the Maastricht University graduates are working in their own or a related field of study. For these two cohorts, the underlying reasons for a horizontal mismatch might differ. Shortly after graduation, a horizontal mismatch is often related to labour market conditions not allowing graduates to find a job that matches the field of study, as well as voluntary choices preferring a job in a different field. II years after graduation, upward job mobility often comes with more 'generic' positions not directly related to the initial field of study.

Table $2 b$

Horizontal match

\begin{tabular}{|l|c|c|c|}
\hline & \multicolumn{4}{|c|}{ \% working in own or related field of study } \\
& $2012-2013$ & $2008-2009$ & $2003-2004$ \\
\hline Humanities and Sciences & 70 & 91 & $\mathrm{X}$ \\
\hline Business and Economics & 77 & 83 & 82 \\
\hline Health, Medicine and Life Sciences & 85 & 90 & 83 \\
\hline Arts and Social Sciences & 59 & 71 & $\mathrm{X}$ \\
\hline Psychology and Neuroscience & 70 & 76 & 85 \\
\hline Law & 80 & 81 & 80 \\
\hline Maastricht University & 77 & 84 & 80 \\
\hline
\end{tabular}

$\mathrm{x}=$ too few cases

Next to differences between the three cohorts, we may observe differences between the faculties. Overall, graduates from the Faculties of Arts and Social Sciences have lower proportions of well-matched graduates. Graduates from

7 For the Faculty of Health, Medicine and life Sciences a strong difference is again visible between Medicine (in all three cohorts 100\% of the graduates are perfectly vertically matched) and Health and Life Sciences. Graduates of the latter studies are vertically matched in $71 \%$ (2012-2013), 88\% (2008-2009), and 89\% (2003-2004) of the cases. 
Psychology and Neuroscience have relatively more difficulty finding a matching job right after graduation, but their horizontal match rate rises sharply as the career progresses. There is little systematic difference between the remaining faculties. It should be noted, however, that within the Faculty of Health, Medicine and Life Sciences, a strong distinction can be seen between the study of Medicine and the studies of Health and Life Sciences. Because of the very specific nature of their study, Medicine graduates show a considerably better horizontal match in all three cohorts (2012-2013: 93\%, 2008-2009: 100\%, 2003-2004: 98\%) than the graduates of Health and Life Science studies (20I2-20I3: 79\%, 2008-2009: 82\%, 2003-2004: 76\%).

\section{Table 3}

Income and working hours

\begin{tabular}{|c|c|c|c|c|c|c|}
\hline & \multicolumn{3}{|c|}{$\begin{array}{l}\text { gross income per month } \\
\text { (median) }\end{array}$} & \multicolumn{3}{|c|}{$\begin{array}{l}\text { regular working hours } \\
\text { per week (median) }\end{array}$} \\
\hline & $\begin{array}{l}2012- \\
2013\end{array}$ & $\begin{array}{l}2008- \\
2009\end{array}$ & $\begin{array}{l}2003- \\
2004\end{array}$ & $\begin{array}{l}2012- \\
2013\end{array}$ & $\begin{array}{l}2008- \\
2009\end{array}$ & $\begin{array}{l}2003- \\
2004\end{array}$ \\
\hline Humanities and Science & 2.791 & $x$ & $x$ & 41 & 40 & 40 \\
\hline Business and Economics & 3.217 & 5.000 & 6.894 & 44 & 45 & 45 \\
\hline Health, Medicine and Life Sciences & 2.694 & 3.455 & 4.400 & 37 & 40 & 36 \\
\hline Arts and Social Sciences & 1.890 & 2.710 & $x$ & 41 & 40 & 38 \\
\hline Psychology and Neuroscience & 2.019 & 2.925 & 3.842 & 36 & 40 & 32 \\
\hline Law & 2.458 & 3.850 & 4.900 & 45 & 40 & 40 \\
\hline Maastricht University & 2.680 & 3.700 & 5.000 & 41 & 40 & 40 \\
\hline
\end{tabular}

$\mathrm{x}=$ too few cases

\section{Income and working hours}

Table 3 shows that, as can be expected, as working experience increases, the median gross income of Maastricht University alumni increases. More specifically, I, 5 year after graduation, Maastricht University alumni have a median income of $€ 2680$ per month, while this increases to $€ 3700$ 6 years after graduation and $€ 5000$ II years after graduation. These numbers closely match the results of previous surveys. Although the income patterns across disciplines slightly differ between the different survey years, Business and Economics graduates consistently show the highest monthly earnings and Arts and Social Sciences graduates the lowest. ${ }^{8}$ It should be noted however, that graduates of the top income discipline (Business and Economics) also report the highest working hours, compared to graduates of the other disciplines.

8 The relatively low median income of Health, Medicine and Life Sciences graduates, is strongly influenced by the relatively low median income of the Health and Life Sciences studies. Medical graduates (a) have a higher starting salary and (b) are the best paid alumni II years after graduation, with a median income of $€$ 7.I64. Due to the structure of their career paths, Medical alumni are also the group that displays the biggest income growth between six and eleven years after graduation.

\section{Aspects of the current job}

Graduates in the 2003-2004 and 2008-2009 cohorts were asked to report the extent to which they thought that their job offered job security, new challenges and career perspectives. Table 4 shows the percentage of graduates who reported that these features applied to a high or very high extent to their current job. Graduates were particularly likely to report that their job is characterized by new challenges: around three quarters of graduates in both cohorts reported that this was the case. Around two thirds reported that their jobs were characterized by a high level of job security, while a little over half of the graduates reported that the job was characterized by good career perspectives. Interestingly, although the older cohorts showed somewhat higher proportions that were satisfied with the security and challenges their jobs offered, they were slightly less satisfied with the career perspectives. It seems likely that the careers of older graduates have stabilized somewhat after a period of early growth and improvement.

\section{Table 4}

Percentage of respondents who reported that these features applied to a high or very high extent to their current job

\begin{tabular}{|c|c|c|c|c|c|c|}
\hline & \multicolumn{2}{|c|}{ job security } & \multicolumn{2}{|c|}{ new challenges } & \multicolumn{2}{|c|}{$\begin{array}{c}\text { career } \\
\text { perspectives }\end{array}$} \\
\hline & $\begin{array}{l}2008- \\
2009\end{array}$ & $\begin{array}{l}2003- \\
2004\end{array}$ & $\begin{array}{l}2008- \\
2009\end{array}$ & $\begin{array}{l}2003- \\
2004\end{array}$ & $\begin{array}{l}2008- \\
2009\end{array}$ & $\begin{array}{l}2003- \\
2004\end{array}$ \\
\hline Humanities and Science & 62 & $\mathrm{x}$ & 67 & $\mathrm{x}$ & 48 & $\mathrm{x}$ \\
\hline Business and Economics & 74 & 64 & 78 & 80 & 57 & 54 \\
\hline Health, Medicine and Life Sciences & 56 & 71 & 81 & 74 & 61 & 49 \\
\hline Arts and Social Sciences & 45 & 65 & 68 & 80 & 47 & 53 \\
\hline Psychology and Neuroscience & 66 & 62 & 63 & 76 & 37 & 47 \\
\hline Law & 80 & 74 & 70 & 73 & 54 & 52 \\
\hline Maastricht University & 63 & 68 & 75 & 77 & 55 & 51 \\
\hline
\end{tabular}

$\mathrm{x}=$ too few cases

The differences between faculties are quite small for the older cohort. There are larger differences for the graduates who were approached 6 years after graduation. Law and Business and Economics graduates in this cohort enjoy a relatively high level of job security, whereas this applies to less than half of their Arts and Social Sciences peers. Graduates from Health, Medicine and Life Sciences and Business and Economics are relatively likely to report a high level of new challenges, as well as relatively good career perspectives. Graduates from the 2008-2009 cohort in the Faculties of Psychology and Neuroscience, Humanities and Science and Arts and Social Sciences score relatively low on these aspects.

\section{International orientation of Maastricht University and its graduates}

It appears that the international orientation of Maastricht University and the fact that English is the main language 
of instruction in many study programs continue to attract increasing numbers of international students for all faculties. It is interesting to see whether this international orientation is extended beyond the time of the study in Maastricht, in the form of high percentages of graduates working abroad. Table 5 shows the percentage of Maastricht University alumni of the various cohorts currently working inside and outside the Netherlands, split by faculty. For Maastricht as a whole, $46 \%$ of the alumni of 20I2-20I3 cohort is working abroad, while the same applies to $34 \%$ of the alumni of the 2008-2009 cohort and $21 \%$ of the alumni of the 20032004 cohort. These numbers include foreign students who returned to their home country after graduation.

Considerable variation exists between the faculties. Graduates of the Arts and Social Sciences and Humanities and Science Faculties are particularly internationally active, while for Law and especially Health, Medicine and Life Sciences graduates' international mobility is relatively rare. The pattern of diminished mobility for the older cohorts can be seen in all faculties, despite the large differences in the absolute level of international mobility.

\section{Table 5}

Percentage of alumi working abroad and percentage feeling that their UM programme offered a good basis for a career in an international labour market

\begin{tabular}{|l|cc|c|c|cc|} 
& \multicolumn{2}{|c|}{$2012-2013$} & \multicolumn{2}{c|}{$2008-2009$} & \multicolumn{2}{c|}{$2003-2004$} \\
& $\begin{array}{l}\text { working } \\
\text { abroad }\end{array}$ & $\begin{array}{c}\text { good } \\
\text { basis }\end{array}$ & $\begin{array}{c}\text { working } \\
\text { abroad }\end{array}$ & $\begin{array}{c}\text { good } \\
\text { basis }\end{array}$ & $\begin{array}{c}\text { working } \\
\text { abroad }\end{array}$ & $\begin{array}{c}\text { good } \\
\text { basis }\end{array}$ \\
\hline Humanities and Science & 82 & - & 64 & 86 & x & x \\
\hline $\begin{array}{l}\text { Business and Economics } \\
\text { Health, Medicine and Life }\end{array}$ & 61 & - & 47 & 79 & 38 & 76 \\
\hline Sciences & 16 & - & 13 & 32 & 10 & 25 \\
\hline Arts and Social Sciences & 69 & - & 65 & 64 & 32 & 24 \\
\hline $\begin{array}{l}\text { Psychology and Neuroscience } \\
\text { Law }\end{array}$ & 42 & - & 51 & 47 & 19 & 29 \\
\hline Maastricht University & 46 & - & 22 & 43 & 10 & 29 \\
\hline x = too few cases & 46 & - & 34 & 52 & 21 & 43 \\
\hline
\end{tabular}

To what extent do alumni feel that the study programme at Maastricht University offered them a good basis for a career in an international labour market? In total, $52 \%$ of the 2008-2009 and 43\% of the 2003-2004 cohort responded that this applied to a high or very high extent. There are large differences between faculties, which broadly correspond with the differences in the proportions working abroad. Graduates from the older cohort are generally less likely to assess that their study provided a good basis for an international career. This could indicate that graduates base their assessment on their own experiences, or alternatively, that the university as a whole has become better at preparing students for an international career. There may be support for this latter interpretation in the fact that graduates of the School of Business and Economics - with its established tradition of an internationally oriented education - are relatively positive about this aspect, and remain positive long after graduation, despite having only the third highest prevalence of working abroad. It may be that the other faculties are beginning to reduce the gap with SBE in this respect.

\section{Satisfaction with Maastricht University}

Finally, alumni were asked how they looked back on their study at Maastricht University and to assess what choices they would make in retrospect. With the benefit of hindsight, would graduates choose the same study at the same university again? In the 20I2-20I3 cohort, $78 \%$ of the alumni would again choose the exact same study at Maastricht University. For the cohorts that graduated in 2008-2009 and 2003-2004, these figures were $80 \%$ and $71 \%$, respectively. Table 6 presents the survey results for the three cohorts per faculty. ${ }^{9}$

Table 6

Percentage of alumi who would again choose the exact same study at Maastricht University

\begin{tabular}{|l|c|c|c|}
\hline & $2012-2013$ & $2008-2009$ & 2003-2004 \\
\hline Humanities and Science & 84 & 86 & $\mathrm{x}$ \\
\hline $\begin{array}{l}\text { Business and Economics } \\
\text { Health, Medicine and Life }\end{array}$ & 84 & 85 & 75 \\
\hline $\begin{array}{l}\text { Sciences } \\
\text { Arts and Social Sciences }\end{array}$ & 75 & 85 & 73 \\
\hline Psychology and Neuroscience & 72 & 75 & 67 \\
\hline Law & 80 & 58 & 67 \\
\hline Maastricht University & 78 & 80 & 60 \\
\hline
\end{tabular}

In general graduates from the Faculties of Health, Medicine and Life Sciences, Business and Economics and Humanities and Science are most often satisfied with their initial choice. Relatively less satisfied were graduates from Psychology and Neuroscience and Arts and Social Sciences.
Within the Faculty of Health, Medicine and Life Sciences, graduates of the Medical studies are significantly more satisfied with their study choice in retrospect. For example, in the 2003-2004 cohort, $75 \%$ of the graduates of Health and Life Sciences would again choose the same study at Maastricht university compared to $90 \%$ of the Medical graduates.




\section{Appendix A}

Table 7

Trends in unemployment ${ }^{1,2}$

\begin{tabular}{|c|c|c|c|c|c|c|c|}
\hline & 2009 & 2010 & 2011 & 2012 & 2013 & 2014 & 2015 \\
\hline & $\mathrm{T}+1$ & $\mathrm{~T}+1$ & $\mathrm{~T}+1$ & $\mathrm{~T}+1$ & $\mathrm{~T}+1$ & $\mathrm{~T}+1$ & $\mathrm{~T}+1$ \\
\hline & $2007-2008$ & $2008-2009$ & $2009-2010$ & $2010-2011$ & 2011-2012 & $2012-2013$ & 2013-2014 \\
\hline Business and Economics & 5,7 & - & 4,9 & 6,0 & 6,3 & 5,7 & - \\
\hline Health and Life Sciences & 0,0 & - & 4,4 & 8,3 & 16,4 & 10,3 & - \\
\hline Medicine & 0,0 & - & 0,0 & 1,7 & 2,5 & 3,3 & - \\
\hline Arts and Social Sciences & 18,5 & - & 23,9 & 25,5 & 33,3 & 13,7 & - \\
\hline Psychology and Neuroscience & 6,1 & - & 11,4 & 16,7 & 25,6 & 7,6 & - \\
\hline Law & 6,0 & - & 8,8 & 7,1 & 14,3 & 16,2 & - \\
\hline \multirow[t]{4}{*}{ Maastricht University } & 5,7 & - & 7,5 & 10,0 & 13,8 & 9,2 & - \\
\hline & 2009 & 2010 & 2011 & 2012 & 2013 & 2014 & 2015 \\
\hline & $T+5$ & $\mathrm{~T}+5$ & $\mathrm{~T}+5$ & $\mathrm{~T}+5$ & $\mathrm{~T}+5$ & $\mathrm{~T}+5$ & $T+5$ \\
\hline & $2002-2003$ & 2003-2004 & $2004-2005$ & $2005-2006$ & $2006-2007$ & $2007-2008$ & $2008-2009$ \\
\hline Business and Economics & 3,2 & 2,2 & 5,4 & 1,9 & 0,0 & 0,0 & 0,9 \\
\hline Health and Life Sciences & 2,4 & 1,7 & 2,7 & 2,1 & 3,1 & 3,5 & 4,3 \\
\hline Medicine & 0,0 & 0,0 & 1,5 & 0,0 & 0,0 & 1,3 & 0,0 \\
\hline Arts and Social Sciences & $x$ & $x$ & 3,8 & 10,1 & 5,7 & 4,8 & 4,4 \\
\hline Psychology and Neuroscience & 1,9 & 7,0 & 10,3 & 4,2 & 0,0 & 4,3 & 7,5 \\
\hline Law & 1,2 & 4,3 & 5,0 & 0,0 & 6,8 & 3,8 & 2,6 \\
\hline \multirow[t]{4}{*}{ Maastricht University } & 2,3 & 2,5 & 4,4 & 2,7 & 3,2 & 2,6 & 2,6 \\
\hline & 2009 & 2010 & 2011 & 2012 & 2013 & 2014 & 2015 \\
\hline & $\mathrm{T}+10$ & $\mathrm{~T}+10$ & $\mathrm{~T}+10$ & $\mathrm{~T}+10$ & $\mathrm{~T}+10$ & $\mathrm{~T}+10$ & $\mathrm{~T}+10$ \\
\hline & 1997-1998 & 1998-1999 & $1999-2000$ & $2000-2001$ & 2001-2002 & $2002-2003$ & 2003-2004 \\
\hline Business and Economics & 0,0 & 3,0 & 2,8 & 0,9 & 0,9 & 0,7 & 1,0 \\
\hline Health and Life Sciences & 0,6 & 0,6 & 2,0 & 1,2 & 3,1 & 3,7 & 0,6 \\
\hline Medicine & 0,0 & 0,0 & 2,6 & 1,8 & 0,0 & 2,0 & 3,6 \\
\hline Arts and Social Sciences & $x$ & $x$ & $x$ & $x$ & $x$ & $x$ & 4,3 \\
\hline Psychology and Neuroscience & 0,0 & 0,0 & 0,0 & 3,8 & 0,0 & 4,9 & 2,0 \\
\hline Law & 0,0 & 1,5 & 0,0 & 6,1 & 1,6 & 0,0 & 1,4 \\
\hline Maastricht University & 0,3 & 1,7 & 2,0 & 2,0 & 2,0 & 2,1 & 1,5 \\
\hline
\end{tabular}

$1=$ too little information on the Faculty of Humanities and Sciences

$2=$ It should be noted that a slightly different definition of employment status was used in the $T+5$ and $T+10$ surveys in 2015 than in the preceding years. Whereas prior to 2015 a respondent had to report a working week of at least 12 hours to be considered as employed, from 2015 onwards the International Labour Organisation (ILO) definition applies, whereby all those who reported at least one hour of work are considered to be employed. In practice this makes little difference, since the vast majority of those employed are working fulltime, but it is possible that a small part of the change in unemployment in 2015 in those cohorts can be attributed to the definition change.

$x=$ too few cases

- = the T+1 survey was not administered in 2010 and still has to be administered in 2015 


\section{Colofon}

Copyright (C 2015, Research Centre for Education and the Labour Market, Maastricht. No part of this publication may be reproduced in any way without prior permission of the Director of ROA.

Research Centre for Education and the Labour Market P.O. Box 616

6200 MD Maastricht

The Netherlands

secretary-roa-sbe@maastrichtuniversity.nl

www.roa.nl

Maastricht University

School of Business and Economics

\section{Layout}

ROA secretary, Maastricht

\section{October 2015}


Researchcentrum voor Onderwijs en Arbeidsmarkt

Postbus 616

6200 MD Maastricht

$\mathrm{T}+31433883647$

F +31 433884914

secretary-roa-sbe@maastrichtuniversity.nl

www.roa.nl

Maastricht University

School of Business and Economics 